\title{
MORPHOMETRIC AND mIDNA ANALYSES OF ARCHAIC SKELETAL REMAINS FROM SOUTHWESTERN SOUTH AMERICA
}

\author{
ANÁLISIS MORFOMÉTRICO Y DE ADNmT DE RESTOS ESQUELETALES \\ ARCAICOS DEL SUROESTE DE SUDAMÉRICA
}

\author{
Germán Manríquez ${ }^{1}$, Mauricio Moraga ${ }^{1}$, Calogero Santoro ${ }^{2,3,4}$, Eugenio Aspillaga ${ }^{5}$, \\ Bernardo T. Arriaza $a^{2,3}$, and Francisco Rothhammer ${ }^{1,2} *$
}

\begin{abstract}
For decades anthropologists have discussed how and when the Americas were peopled. The prevailing view is that the first Paleoindians, ancestors of the Amerindians, arrived from Asia and Beringia to the American continent using a Pacific coastal route in pre-Clovis times. In this article skeletal remains dated 9000-4000 BP, excavated from archaeological sites in northern, central and southern Chile, were analyzed using geometric morphometric and ancient mtDNA techniques. Results indicate that the ancient cranial material from southwestern South America exhibit a wide range of cranial vault shape variation which is independent of chronology. mtDNA restriction and sequence analysis performed on the same skeletal remains, revealed only the presence of the main four founding mtDNA haplogroups (A, B, C and D) as early as 9,000 BP. Our results using morphometric and molecular mtDNA haplogroup data show that human populations inhabiting the Americas during archaic times can not be considered as belonging to two different groups on the basis of analyzed data. These results are consistent with those recently obtained using complete sequence mtDNA analyses.
\end{abstract}

Key words: Paleoindian and archaic crania; geometric morphometrics; ancient mtDNA; peopling of America.

Durante décadas los antropólogos han discutido cómo y cuándo América fue poblada. El punto de vista predominante al respecto plantea que los primeros paleoindios, población amerindia ancestral, llegó en una época pre-Clovis desde Asia y Beringia utilizando como ruta la costa pacífica del continente. En el presente trabajo se analizan mediante morfometría geométrica y técnicas de ADNmt antiguo restos esqueletales de 9.000-4.000 años a.p., excavados de sitios arqueológicos del Norte, Centro y Sur de Chile. Nuestros resultados muestran que el material craneano arcaico del suroeste de América exhibe un amplio rango de variación de la forma de la bóveda, la cual es independiente de la cronología de los cráneos. El análisis del ADNmt realizado en los mismos restos esqueletales revela la presencia sólo de los cuatro haplogrupos fundadores $(A, B, C$ y D) desde los 9.000 a.p. Los resultados obtenidos a partir de datos morfométricos y de mtDNA muestran que, considerando los rasgos analizados, las poblaciones humanas que habitaron América durante la época arcaica no constituyen dos grupos diferentes. Estos resultados son consistentes con los análisis de secuencias completas de DNA mitocondrial recientemente obtenidos.

Palabras claves: cráneos arcaicos y paleoindios, morfometría geométrica, ADNmt antiguo, poblamiento de América.

The aim of this study is to present a geometric morphometric analysis of the earliest skeletal remains uncovered in archaeological sites along the southwestern coast of South America. This ancient skeletal material may contribute to the debate about the colonization of the Americas, which has been the object of recent reviews (Goebel et al. 2008; Waters and Stanford 2008; Gonzalez-Jose et al. 2008;
Dillehay 2009; Rothhammer and Dillehay 2009). Of particular interest is the comparison between this ancient skeletal remains and Brazilian skeletal material showing two cranial morphologies which apparently could be traced back to two different migrational events (Neves and Hubbe 2005). Additionally, ancient mtDNA data obtained from the skeletal remains from Chilean archaeological

\footnotetext{
1 Programa de Genética Humana, Instituto de Ciencias Biomédicas, Facultad de Medicina. Universidad de Chile. Santiago, Chile.germanmanriquezs@gmail.com; mmoraga@med.uchile.cl

2 Instituto de Alta Investigación, Universidad de Tarapacá. Arica, Chile. calogero_santoro@yahoo.com; barriazaarica@gmail.com *Corresponding author: frothham@med.uchile.cl

3 Departamento de Antropología, Universidad de Tarapacá. Arica, Chile.

4 Centro de Investigaciones del Hombre en el Desierto, Universidad de Tarapacá. Arica, Chile.

5 Departamento de Antropología, Facultad de Ciencias Sociales, Universidad de Chile. Santiago, Chile. easpilla@uchile.cl
} 
sites were analyzed, in order to search for molecular signatures of these two hypothetical migrations.

The first colonization of South America may have occurred along the western coast, exihibiting an early pattern of maritime adaptation and coastal navigation and /or through the Andean Highlands (Rothhammer and Dillehay 2009). Solid archaeological evidence dating from $12500 \mathrm{BP}$, uncovered in southern Chile, indicates that the arrival of the first colonizers to this region occurred during pre-Clovis times (Dillehay 1999). Archaeological evidence provided radiocarbon dates close to $1,0000 \mathrm{BP}$ for the sites of Las Vegas in Ecuador and Quebradas Tachahuay and Jaguay in Perú (Keefer et al. 1998; Sandweiss et al.1998; Stothert 1998; Wisner 1999). Chronologies between 10,000 and 8,000 BP are characteristic of southwestern South America's early sites of Quebrada de Acha, Huentelauquen, Piuquenes Cave, Tagua Tagua (Cuchipuy), Monte Verde and Baño Nuevo (Dillehay 1999; Kaltwasser et al. 1984; Mena et al. 2003; Muñoz et al. 1993; Schiappacasse and Niemeyer 1984).

\section{Material and Methods}

\section{Cranial samples}

Twenty seven Early, Middle, and Late Archaic skulls from Northern, Central and Southern Chile (Table 1) were photographed in lateral and frontal views with a FujiFilm FinePix 6900 digital camera under controlled distance and light conditions, and digitilized to obtain matrices of landmark coordinates
(Table 2, Figure 1). Because of the partial or total fragmentation of facial bones belonging to the skulls from Tagua Tagua (Cuchipuy), the morphometric analysis of the sample was based on the register of cranial vaults. For comparative purposes we considered three paradigmatic Brazilian skulls from the region of Lagoa Santa studied by the authors of the Dual Migration Hypothesis (Neves and Hubbe 2005; Neves et al. 2003; Neves et al. 2005). Ideally, a larger sample should have been included in the analysis, but access to this published material was the unique available source. It is worth highlighting though that given the craniometric homogeneity of Lagoa Santa remains, the sample may serve for comparative purposes. Cultural and chronological information about the Chilean skulls was obtained from records available at the institutions housing the collections: Museo Arqueológico de San Miguel de Azapa, Arica; Museo Nacional de Historia Natural, Santiago; Facultad de Ciencias Sociales Universidad de Chile, Santiago; Museo Regional, Rancagua and Museo de Arte Precolombino, Santiago.

\section{mtDNA Samples}

Ancient mtDNA was extracted from 55 samples of skeletal remains belonging to 48 individuals. Positive results obtained from 30 of our sample are shown in Table 3. Bone fragments (11 samples from 6 individuals) were obtained from Quebrada de Acha (Muñoz et al. 1993). Three of these samples are dated $7,570 \pm 40$, BP $8,970 \pm 255 \mathrm{BP}$, and $8,120 \pm 90 \mathrm{BP}$. In addition, 18 samples from 17 individuals from the

Table 1. Geographic location, archaeological sites, number of observations and chronologies of prehistoric groups analysed. Ubicación geográfica, sitios arqueológicos, número de observaciones y cronologías de los grupos prehistóricos analizados.

\begin{tabular}{cccccc}
\hline Geographic location & Archaeological site & $\begin{array}{c}\text { Cranial } \\
\text { morphology } \\
\text { N }\end{array}$ & $\begin{array}{c}\text { mtDNA } \\
\text { N }\end{array}$ & $\begin{array}{c}\text { Approximate } \\
\text { Chronology } \\
\text { years BP }\end{array}$ & Archaic Period \\
\hline $\begin{array}{c}\text { Northern Chile } \\
18^{\circ} 30^{\prime} \mathrm{S}-19^{\circ} 15^{\prime} \mathrm{S}\end{array}$ & $\begin{array}{c}\text { Quebrada de Acha } \\
\text { Camarones 14 }\end{array}$ & 3 & 4 & $9,000-7,500$ & Early \\
$70^{\circ} 16^{\prime} \mathrm{W}$ & Playa Miller 8 & 3 & 4 & 7,500 & Middle \\
Late & Morro 1 and 1-6 & 3 & - & 6,000 & Late \\
Central Chile & Tagua Tagua & 8 & $4,000-4,000$ & Middle \\
$34^{\circ} 27^{\prime} \mathrm{S}$ & (Cuchipuy) & & - & 7,000 & Middle \\
$71^{\circ} 07 \mathrm{~W}$ & Santa Amelia & 4 & 4 & 9,000 & Early \\
Southern Chile & & & & & \\
$45^{\circ} 17^{\prime} \mathrm{S}$ & Baño Nuevo & 1 & & & \\
$17^{\circ} 32^{\prime} \mathrm{W}$ & & & & & \\
\hline
\end{tabular}

* Moraga et al. 2005. 
Table 2. Name, definition and type (sensu Bookstein 1991) of the landmarks shown in Figure 1

(*Pseudolandmark, defined geometrically as the orthogonal projection onto the vault of the middle point between two anatomical landmarks, as is shown in Figure 1).

Nombre, definición anatómica y tipo (según Bookstein 1991) de hitos mostrados en la Figura 1

(*Pseudohito, definido geométricamente como la proyección ortogonal sobre la bóveda del punto medio de la cuerda entre dos hitos anatómicos, como se muestra en la Figura 1).

\begin{tabular}{|c|c|c|c|}
\hline Landmark & Name & Definition & Type \\
\hline 1 & Nasion & $\begin{array}{l}\text { Intersection of the frontal-nasal suture with the medio-sagittal plane (Buikstra and } \\
\text { Ubelaker 1994) }\end{array}$ & I \\
\hline 2 & Glabella & $\begin{array}{l}\text { The most anterior point of the middle line of the frontal bone, generally located over } \\
\text { the frontal-nasal suture (Buikstra and Ubelaker 1994) }\end{array}$ & II \\
\hline 3 & Bregma & $\begin{array}{l}\text { The middle line point from the ectocranium where the coronal and sagittal sutures } \\
\text { intersect (Buikstra and Ubelaker 1994) }\end{array}$ & I \\
\hline 4 & Asterion & $\begin{array}{l}\text { Point located at the junction of the lamboid suture(,) the occipitomastoid suture and } \\
\text { the parietomastoid suture (Buikstra and Ubelaker 1994) }\end{array}$ & I \\
\hline 5 & Vault & $\begin{array}{l}\text { Orthogonal projection on the frontal bone of the middle point between Bregma and } \\
\text { Asterion }\end{array}$ & * \\
\hline 6 & Inion & $\begin{array}{l}\text { Point located at the base of the external occipital protuberance, corresponding to the } \\
\text { intersection of the middle sagittal plane with a (line) tangent to the most superior } \\
\text { convexity of the right and left superior nuchal lines (Bass 1987) }\end{array}$ & II \\
\hline
\end{tabular}

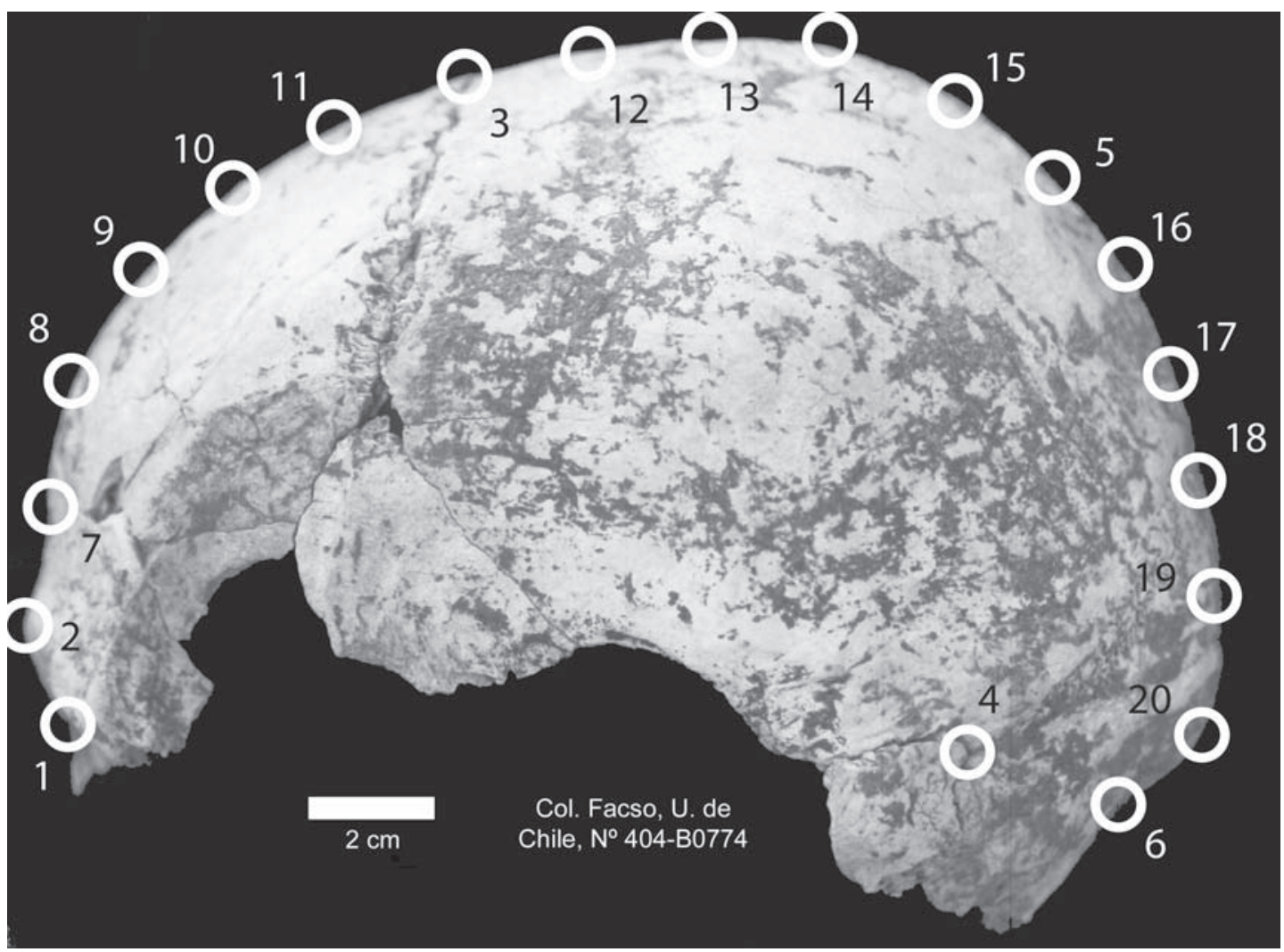

Figure 1. Anatomical location of the landmarks $(1-4,6)$, semilandmarks (7-20) and one pseudolandmark (5) used in this study in order to obtain the landmark data.

Ubicación anatómica de los hitos (1-4, 6), semihitos (7-20) y un pseudohito (5) utilizados en el presente estudio con el fin de obtener los datos de coordenadas. 
Table 3. Amerindian haplogroups in Paleoindian and Archaic prehistoric groups of southwestern South America. Haplogrupos amerindios en los grupos prehistóricos paleoindios y arcaico del sudoeste de Sudamérica.

\begin{tabular}{rrrccrr}
\hline & Quebrada de Acha & Camarones 14 & Morro 1, 1-6 & $\begin{array}{c}\text { Tagua Tagua } \\
\text { (Cuchipuy) }\end{array}$ & Baño Nuevo & Total \\
\hline A & $1(0.25)$ & $1(0.25)$ & $7(0.57)$ & $0(0)$ & $0(0)$ & $9(0.3)$ \\
B & $0(0)$ & $2(0.5)$ & $5(0.36)$ & $0(0)$ & $3(0.75)$ & $10(0.33)$ \\
C & $2(0.5)$ & $1(0.25)$ & $1(0.07)$ & $4(1)$ & $1(0.25)$ & $9(0.3)$ \\
D & $1(0.25)$ & $0(0)$ & $1(0.07)$ & $0(0)$ & $0(0)$ & $2(0.07)$ \\
T & 4 & 4 & 14 & 4 & 4 & 30 \\
\hline
\end{tabular}

( ) Relative frequency.

archaic site of Camarones 14 dated between 7,360 BP and 6,880 BP (Schiappacasse and Niemeyer 1984) were included. Furthermore, skeletal fragments (22 samples from 21 individuals) exhumed in Cuchipuy were analyzed. There are several radiocarbon dates for this site spanning a long time interval between 11,380 BP and 6,130 BP (Kaltwasser et al. 1984). The skeletal remains were dated between 8,070 BP and 6,105 BP (Kaltwasser et al. 1984). Finally, skeletal remains from four individuals exhumed in southern Chile at the site of Baño Nuevo-1, provided ancient mtDNA. Individual 1 (neonate, unknown sex) was dated 8,950 $\pm 50 \mathrm{BP}$, individual 2 (20-25 male) was dated $8,850 \pm 50 \mathrm{BP}$, individual 3 ( $40-45$ female) was dated $8,950 \pm 60 \mathrm{BP}$, and finally individual 4 (neonate, unknown sex) 8,945 $\pm 40 \mathrm{BP}$ (Mena et al. 2003). For comparative purposes a sample of the Morro 1/ 1-6 site located in the Azapa valley dated 4,000 BP was also included (Moraga et al. 2005).

\section{Geometric morphometric analysis of cranial vault shape variation}

The geometric morphometric approach allows for the partitioning of shape and size components of form using landmark coordinates as raw data (rev. Adams et al. 2004; O'Higgins 2000; Slice 2007). In order to analyze cranial vault shape variation a set of 6 anatomical landmarks, 13 semi-landmarks, and one pseudolandmark, were digitized using the TpsDig program (Rohlf 2005a) (Table 2 and Figure 1). The semi-landmarks were incorporated into the map of landmark coordinates in order to register information about curvatures, not available directly from the landmark coordinates (Bookstein 1991, 1997). In order to align the matrices and to filter out the effects of scale, location, and rotation, a superimposition by Generalized Procrustes Analysis (GPA) (Dryden and Mardia 1998) was performed using TpsRelwarp software (Rohlf 2005b). Basically, this procedure consists in scaling all landmark matrices to a unit centroid size, and thereafter translating and superimposing their centroids by rotation. The squared Procrustes distances between homologous landmarks on each configuration are this way minimized, sharing the specimens as a result a common system of coordinates. Shape variables represented by these new coordinates can therefore be treated with standard multivariate statistical tests. Alternatively, shape variation among crania can be visualized through thin-plate spline mapping of the specimens onto the corresponding shape variables (Bookstein 1991). This function allows to visualize skull shape variation as deformed Cartesian grids, as well as vectors, after superimposing a non-deformed consensus matrix configuration obtained by GPA, to matrices representing the individual skulls of the sample.

In order to characterize cranial morphology, the cephalic index (CI) defined by the ratio between head width (HW= greatest breadth, at right angles to median plane) and head length $(\mathrm{HL}=$ summit of glabella to farthest occipital point) ( $\mathrm{CI}=\mathrm{HW} /$ $\mathrm{HL} \times 100$ ) was calculated. For this purpose the TpsDig (Rohlf 2005a) routine for registering interlandmark distances in frontal and lateral views was carried out The null hypothesis about the absence of significant shape variation between skulls belonging to different chronological periods, and showing different cephalic indexes was tested by a one-way ANOVA for interlandmark data (CI) and by a two-way MANOVA using TpsReg software (Rohlf 2005b) and a Wilk's Lambda test for the landmark data. To know the degree of morphological relatedness among specimens, a 
dendrogram based on the Procrustes (morphometric) distances among consensus configurations representing the mean skull shape from each archaeological site was obtained (clustering method, UPGMA, NTSYSpc v2.11x, Applied Biostatistics Inc.). The value of correlation among morphometric, chronological and geographical distance matrices was then analysed after a two-way Mantel Test (NTSYS-pc v2.11x, Applied Biostatistics Inc.).

\section{DNA extraction and contamination precautions}

DNA was extracted from bone fragments which were polished to eliminate external contamination with recent DNA due to previous handling. Later, the bone fragments were irradiated with UV light for 15 minutes. Bone fragments were powdered by means of a mill cooled by liquid nitrogen (Spex CertiPrep). DNA extraction from the bone samples was carried out using a modified protocol of Höss and Pääbo (1993). Approximately 0.5 to 1 gram of the powdered samples were incubated for 24 hours in $8 \mathrm{ml}$ of $0.5 \mathrm{M}$ EDTA pH: 8.0 at room temperature with sporadic agitation; solids were pelleted by centrifugation and $5 \mathrm{ml}$ of extraction buffer was added (5 M GuSCN, $100 \mathrm{mM}$ Tris-HCl pH: 7.2, 2.5\% $\mathrm{N}$-lauryl sarcosine), and incubated at $55^{\circ} \mathrm{C}$ for 8 to 16 hours with agitation. The supernatant was moved to a new tube and $50 \mu \mathrm{l}$ of silica suspension was added. The silica was washed twice with extraction buffer and twice with $70 \%$ ethanol and finally eluted with TE buffer (10mM Tris- $\mathrm{HCl} \mathrm{pH}: 8.5$, $0.1 \mathrm{mM}$ EDTA). All the procedures considered in the extraction were carried out in a laboratory used exclusively to the prosecution of ancient samples. Only disposable sterile plastic materials were used and the reagents as well as the samples were always manipulated below a laminar flow cabinet. One or two blank extractions were included in every set. The samples that resulted positive were replicated at different times with a new stock of reagents, from another fragment of bone.

\section{PCR amplification and RFLP analysis}

The geometric morphometric approach was complemented with ancient mtDNA haplogroup and sequence data analysis of the same prehistoric populations. A primer set as described by Handt for the RFLP analyses was used, which amplify fragments in the range of 75 to $121 \mathrm{bp}$ (Handt et al. 1996). The hot-start PCR was carried out using 2.5 units of Ampli-taq Gold DNA polymerase Applied Biosystems, $200 \mathrm{nM}$ of each deoxinucleotide, 25 pmoles of each primer, $100 \mu \mathrm{g}$ of BSA and the appropriate buffer. The PCR conditions were: one cycle at $95^{\circ} \mathrm{C}$ for $9 \mathrm{~min}$, followed by 45 cycles at $93^{\circ} \mathrm{C}$ for $45 \mathrm{sec}, 55^{\circ} \mathrm{C}$ for $45 \mathrm{sec}, 72^{\circ}$ for $45 \mathrm{sec}$, and finally one cycle at $72{ }^{\circ} \mathrm{C}$ for $3 \mathrm{~min}$. All PCR reactions were repeated at least twice from different DNA extractions from the same individual, including negative DNA extraction and PCR controls. Haplogroup determination was carried out through enzyme restriction (RFLP). The samples were analyzed by enzymatic digestion, using $\mathrm{Hae}$ III for haplogroup A, HincII for haplogroup $\mathrm{C}$ and $A l u \mathrm{I}$ for haplogroup D. The resulting restriction fragments and the PCR product including region $\mathrm{V}$, defining haplogroup $\mathrm{B}$, were analyzed by electrophoresis on 3\% NuSieveAgarose (2:1) (FMC BioProducts gels).

The genetic affinities among populations were evaluated from the haplogroup frequencies obtained using Nei's (1978) and modified Rogers distances (Wright 1978). Both distances gave essentially the same results, we report Nei's distance. The distance matrix was represented by means of a neighborjoining tree (Saitou and Nei 1987) built with the program MEGA 4.0 (Tamura et al. 2007).

\section{Results}

\section{Geometric morphometric analysis}

The morphometric analysis of Chilean samples of the Early Archaic (9,000 BP), the Middle Archaic (7,500-7,000 BP) and the Late Archaic (6,000$4,000 \mathrm{BP}$ ) periods revealed a wide range of cranial vault shapes. The distribution of specimens along the first two shape variables (RW1 + RW2 $=57.6 \%$ ), shows two extreme phenotypes, respectively characterized by elongated and contracted vaults (Figure 2). The more elongated vault shape is associated with the inferior and posterior expansion of Inion, the more anterior location of Glabella, the flattening of Bregma, and the posterior expansion of the vault in the sagittal plane. The skulls with a more contracted vault show the opposite anatomical changes, characterized by an anterior contraction of Inion, the relatively most inferior location of Glabella, the most posterior location of Nasion, the expansion of Bregma and the contraction of the vault in the sagittal plane. Despite 


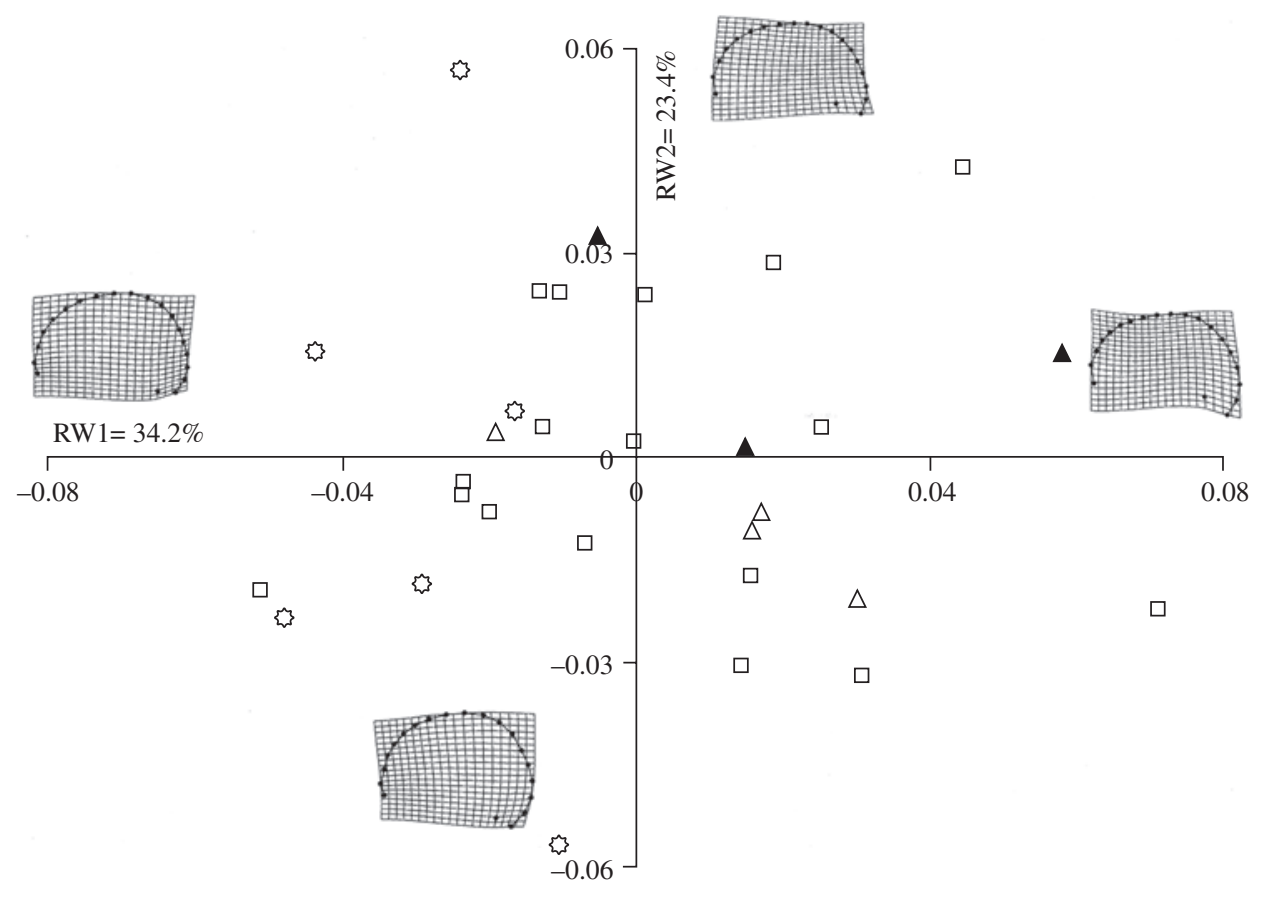

$\Delta$ Early Archaic (Brazil) $\Delta$ Early Archaic (Chile) $\square$ Middle Archaic (Chile) is Late Archaic (Chile)

Figure 2. Relative warp (RW) analysis of Early, Middle, and Late Archaic skulls from archaeological sites from Southern-western South America. The grids represent the extreme values of deformation along the first two relative warp (RW) axes, which are analogous to the principal component axes of traditional multivariate analysis.

Análisis de Relative warps de los cráneos arcaicos tempranos, medios y tardíos de los sitios arqueológicos del sudoeste de Sudamérica. Las grillas representan los valores extremos de la deformación a lo largo de los dos primeros componentes de la forma $(R W)$, análogos del análisis de componentes principales tradicional.

the prevalence of dolicocephalic skulls, as revealed by independently taken linear size measurements (means $\mathrm{CI}_{\text {Early and Middle archaic samples }}=0.68, \mathrm{CI}_{\text {Late }}$ archaic sample $=0.72)\left(\mathrm{F}_{(2,27)}=1.415, \mathrm{p}=0.26\right.$ after one-way ANOVA), the two-way MANOVA for landmark data, showed significant differences in skull shape variation due to geographical origin (Wilk's Lambda $\left.=0.329, \mathrm{Fst}_{(8,21)}=5.363, \mathrm{p}=9.38 \mathrm{E}-004\right)$, but not to chronological period (Wilk's Lambda $=0.538$, Fst $\left._{(8,21)}=2.251, \mathrm{p}=0.07\right)$. These results indicate that the cranial samples used in this study exhibit a wide range of shape variation, being the Central-southern skulls more elongated $\left(\mathrm{HL}_{\text {Northern }}=17.18 \pm 0.82 \mathrm{~cm}\right.$, $\mathrm{HL}_{\text {Central-Southern }}=18.98 \pm 0.61 \mathrm{~cm}$, T-test, $\mathrm{p}<<0.001 ; \mathrm{HW}_{\text {Northern }}=12.11 \pm 0.67 \mathrm{~cm}, \mathrm{HW}_{\text {Central- }}$ Southern $=12.79 \pm 1.18 \mathrm{~cm}$, T-test, $\mathrm{p}=0.072$ ), and that this variation does not depend on the chronology of the samples. The degree of taxonomic concordance between morphological and geographical distances $(\mathrm{r}=0.142$, Mantel $\mathrm{t}$-test $\mathrm{t}=0.5896$ Prob.random $\mathrm{Z}<$ obs.Z: $\mathrm{p}=0.7223$ ) and between morphological and chronological distances ( $\mathrm{r}=-0.31$, Mantel t-test $\mathrm{t}=-1.2625$ Prob. Random Z<obs.Z: $\mathrm{p}=0.1034$ ) was not statistically significant. The same result was obtained when the association between geographical and chronological distances was studied $(\mathrm{r}=-0.04453$, Mantel $\mathrm{t}$-test $\mathrm{t}=-0.1938$ Prob random $\mathrm{Z}<$ obs $\mathrm{Z}$ : $\mathrm{p}=0.4232$ ). The absence of a significant correlation between skull shape variation and chronology is clearly illustrated in the dendrogram based on morphological (Procrustes) distances (Figure 3). The relative location of the archaic skulls from the most archaic Brazilian archaeological sites is a representative example of this.

\section{Genotyping of human remains}

From a total of 55 samples (bone fragments) from 48 individuals, 40 were amplified for at least one PCR fragment. Amplification was not possible to obtain for the remaining bone fragments. Four individuals from Acha, four from Camarones 14, 
four from Cuchipuy and four from Baño Nuevo site yielded amplification of the PCR fragments that harbor the classical mtDNA markers allowing haplogroup identification. This represented a success of $33 \%$ for extraction and amplification $(67 \%$ Acha

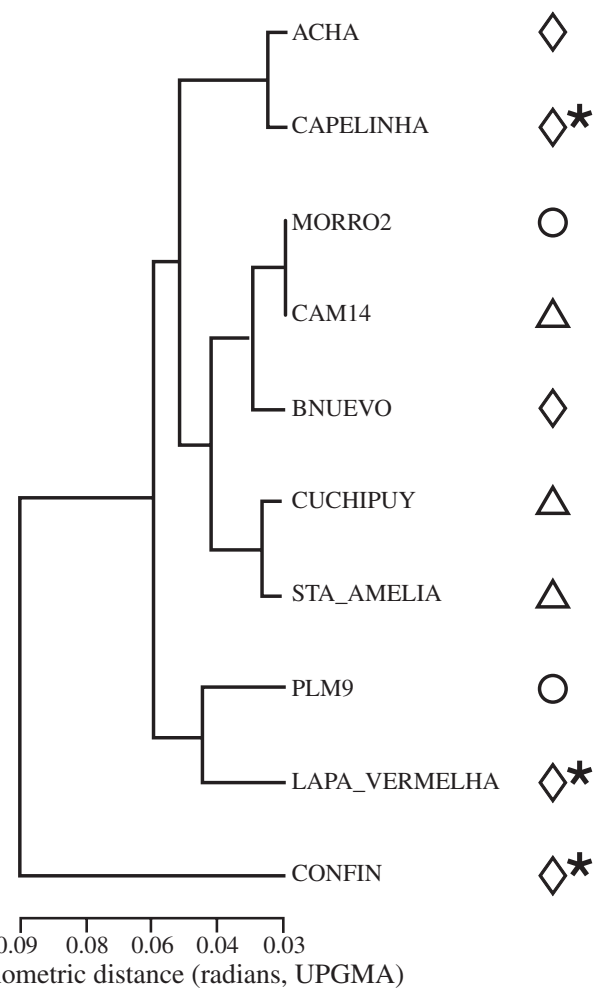

Figure 3. Dendrogram based on Procrustes (radians) distances among consensus configurations representing the mean skull shape from the archaeological sites considered in this study (clustering method UPGMA; diamond = Early Archaic, triangle $=$ Middle Archaic, circle $=$ Late Archaic, $*=$ archaeological site from Brazil) (details about corresponding chronological period and sample size in Table 1).

Dendrograma basado en las distancias de Procusto (radianes) entre las configuraciones de consenso que representan la forma promedio del cráneo de los sitios arqueológicos considerados en este estudio (método de agrupación, UPGMA; rombo = arcaico temprano, triángulo = Arcaico Medio, círculo = Arcaico Tardío, *= sitio arqueológico de Brasil) (detalles sobre cronología y tamaños muestrales en Tabla 1). site, 23\% Camarones site, 19\% Cuchipuy site, 100\% Baño Nuevo site), a reasonable outcome considering the antiquity of the samples. It is noteworthy that the finding is not directly correlated with the antiquity of the samples, probably because the weather and soil conditions were extremely different at the four sites. Genotyping of Cuchipuy samples was a specially hard task, probably due to the level of damage and / or to the low amount of DNA present in the samples (Gilbert 2003). In southwestern South America we found that haplogroup B exhibited the highest frequency (33\%) followed by A and C $(30 \%)$ and D (7\%) (Table 3).

The NJ dendrogram (Figure 4) derived from the distances matrix (Table 4) confirms the results found by morphological approach, i.e. the absence of segregation between the samples belonging to early, middle or late archaic periods.

In an attempt to improve the resolution of the analyses, the hypervariable region I (HV1) was amplified and sequenced, by means of the amplification of five overlapping fragments. As to the determination of PCR-RFLP haplogroups, the amplification of Cuchipuy samples exhibited a very low efficiency, obtaining results for only some fragments of HV1 in
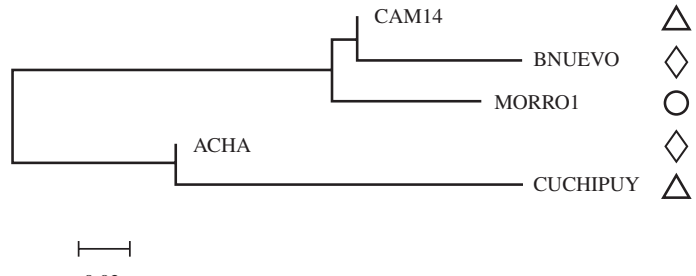

0.02

Figure 4. Dendrogram based on genetic distances Matrix (Nei 1978) (clustering method NJ; diamond = Early Archaic, triangle $=$ Middle Archaic, , circle $=$ Late Archaic) (details about chronological period and sample size in Table 1).

Dendrograma basado matriz de distancias genéticas (Nei 1978) (método de agrupación, NJ; rombo= Arcaico Temprano, triángulo $=$ Arcaico Medio, círculo $=$ Arcaico Tardío) (detalles sobre cronología y tamaños muestrales en Tabla 1).

Table 4. Genetic distance matrix based in frequency of haplogroups from Table 3 (Nei 1978).

Matriz de distancias genéticas basada en frecuencia de haplogrupos de Tabla 3 (Nei 1978).

\begin{tabular}{ccccc}
\hline & Quebrada de Acha & Camarones 14 & Morro 1, 1-6 & Tagua Tagua (Cuchipuy) \\
\hline Camarones 14 & .079 & & & \\
Morro 1, 1-6 & .117 & .003 & & \\
Tagua Tagua (Cuchipuy) & .067 & .249 & .433 & .349 \\
Baño Nuevo & .234 & .000 & .130 & .30 \\
\hline
\end{tabular}


7 individuals. The polymorphisms observed did not contribute significantly in identifing subhaplogroups. A similar situation was observed for the sample of Acha where only partial sequences for four individuals were observed (data not shown). Although the sequences did not contribute to the identification of subhaplogroups, the polymorphisms found corroborated the haplogroup distribution obtained by PCR-RFLP.

\section{Discussion}

The skeletal remains examined in this study were exhumed in Quebrada de Acha, Quebrada de Camarones, Cuchipuy, Santa Amelia and Baño Nuevo, and are among the most ancient exhumed in South America (Table 1). Given the absence of more skeletal remains from these or other ancient sites, it is plausible to accept that this group of samples is representative of the first colonizers arriving in southwestern South America using a coastal route, or through the Andean highlands.

On the basis of a standard craniometrical analysis of Brazilian Lagoa Santa samples, including a comparison with late prehistoric and modern Amerindian material, it has been suggested that cranial variation in the Americas reveals two different patterns termed Paleoamerican and Amerindian, and that both patterns could be traced back to separate migrations originated at different geographic locations and time points (Neves and Hubbe 2005). Our craniometric results do not reveal the presence of two separate morphological patterns related to chronology and /or geography such as in Brazil, but a wide range of cranial variation which is independent from both chronology and geography (Figure 2). Thus, the early archaic samples are centrally located and tightly clustered, exhibiting limited variation particularly along the y-axis. Middle archaic samples are also centrally located but widely distributed in both dimensions, whereas late archaic samples lack diversity along the $\mathrm{x}$-axis, but are still about as variable as the middle archaic samples, with the difference that they are restricted to the negative $\mathrm{x}$-axis. Although this pattern may be interpreted as a bottleneck before the middle archaic period, followed by a population expansion, the statistical results failed to show a significant association.

Interestingly, considering the CI values as well as the geographical origin of the samples, and due to head length contribution, the skulls may be classified as dolichocephalic. This finding is consistent with the classical argument of South American physical anthropologists about the dolicocephalic morphology of most ancient skulls compared to more recent ones belonging to agricultural societies. However, when the shape and size components of cranial form are partitioned, the main "cephalic types" of classical physical anthropology are all well represented in the morphometric shape space (i.e. dolicocephalic, mesocephalic and brachicephalic ones), (Figure 2) clustering independently of the chronological origin of the samples (Figure 3).

Similarly to previous studies of prehistoric populations (Carlyle et al. 2000; Kaestle and Smith 2001; Parr et al. 1996; Stone and Stoneking 1996, 1998) ancient mtDNA restriction and sequence analysis revealed the presence of classical mtDNA founding lineages. As early as 9,000 BP, the four founding haplogroups were present and no haplogroups different to the Amerindian ones have been described. These results support the one-way migration hypothesis which recently has been also positively contrasted using complete sequences of mtDNA (Fagundes et al. 2008; Perego et al. 2009; Tamm et al. 2007), and even craniometric distance data (González-José et al. 2008)

It is noteworthy that, to our knowledge, haplogroup A had not been found in the Americas in Paleoindian or Early Archaic skeletal remains. Until now the oldest member of this haplotype in the New World dated to 4,504 \pm 105 years BP (Kaestle and Smith 2001). The presence of haplogroup B in southern Chile by 8,000 BP is also unexpected, since this haplogroup had not been found in present-day populations southern of 43 degrees south latitude. Due to the same reason some previous colonization models based on mtDNA evidence considered that $\mathrm{B}$ was introduced by a separate, more recent migration (Lalueza-Fox et al. 1997; Torroni et al. 1993).

The haplogroup frequency distribution of Archaic remains was not found to be statistically different from a very large sample of extant Amerindians living in major ecogeographic areas of South America (Moraga 2003).

\section{Conclusions}

Our craniometric analysis in southwestern South America revealed a wide range of cranial morphologies, including Paleoamerican and Amerindian morphology as described in Brazil. This variation is not explained by the chronological period 
of the skulls. Since according to recent molecular evidence the eastern part of South America was probably colonized by western subgroups (Wang et al. 2007), it is difficult to exclude stochastic microevolutionary events as the main explanation for the dual craniometric pattern observed in Brazil.

Based on recent nuclear molecular genetic evidence, the first colonization of America has been characterized as a pre-Clovis single origin serial founding microevolutionary process (Rothhammer and Dillehay 2009; Wang et al. 2007). The fragmentary state of our mtDNA data due to the bad preservation of Chilean skeletal remains, allow us only to conclude that by $9,000 \mathrm{BP}$ the four classic haplogroups were already present in South America. Nevertheless, extensive mtDNA haplogroup studies performed in extant Ameridian populations of Chile provide strong support to this model (García et al. 2006).

Our results using morphometric and molecular mtDNA haplogroup data clearly show that on the basis of analyzed traits, human populations inhabiting the Americas during prearchaic times can not be considered as belonging to two different groups. These results are consistent with those recently obtained using complete sequence mtDNA analyses (Fagundes et al. 2008; Perego et al. 2009; Tamm et al. 2007)

Acknowledgements: We thank Francisco Mena (Museo Chileno de Arte Precolombino, Santiago), Oscar Espoueys (Museo Nacional de Historia Natural, Santiago) and Mario Henríquez (Museo Regional de Rancagua, Rancagua) for making ancient skeletal remains in their care available to us for geometric morphometric and mtDNA analyses. We also thank Claudia Trajtemberg for revising critically the English text and anonymous reviewers for improving with there comments earlier versions for this paper. Grant sponsors: Fondecyt 1050279, 1095006, 11060442 , Anillos ACT-096, and Convenio de Desempeño UTA Mecesup-2.

\section{References Cited}

Adams, D.C., F.J. Rohlf, and D.E. Slice

2004 Geometric morphometrics: Ten years of progress following the "revolution". Italian Journal of Zoology 71:5-16.

Bass, W.M.

1987 Human Osteology: A Laboratory and Field Manual $3^{\text {rd }}$ edition. Special Publication No.2 of the Missouri Archaeological Society. Missouri Archaeological Society, Inc., Columbia.

Bonatto, S.L., and F.M. Salzano

1997 A single and early migration for the peopling of the Americas supported by mitochondrial DNA sequence data. Proceedings of the National Academy of Sciences USA 94(5):1866-1871.

Bookstein, F.L.

1991 Morphometric Tools for Landmark Data: Geometry and Biology. Cambridge University Press, Cambridge.

1997 Landmarks methods for forms without landmarks: Localizing groups differences in outline shape. Medical Image Analysis 1:225-243.

Buikstra, J.E., and D.H. Ubelaker

1994 Standards for Data Collection from Human Skeletal Remains. Research Series, $\mathrm{N}^{\circ} 44$. Arkansas Archaeological Survey, Fayetteville.

Carlyle, S.W., R.L. Parr, M.G. Hayes, and D.H. O'Rourke 2000 Context of maternal lineages in the Greater Southwest. American Journal of Physical Anthropology 113:85-101.

Dillehay, T.D.

1999 The late Pleistocene Cultures of South America. Evolutionary Anthropology 7:206-216.

2008 Probing deeper into first American studies. Proceedings of the National Academy of Sciences USA 106:971-978.

Dryden, I.L., and K.V. Mardia

1998 Statistical Shape Analysis. Wiley, New York.
Fagundes, N., R. Kanitz, R. Eckert, A. Valls, M. Bogo, F. Salzano, D. Smith, W. Silva, M. Zago, A. Ribeiro-dos-Santos, S. Santos, M. Petzl-Erler, and S. Bonatto

2008 Mitochondrial population genomics supports a single Pre-Clovis origin with a coastal route for the peopling of the Americas. American Journal of Human Genetics 82(3):583-592.

García, F, M. Moraga, S. Vera, H. Henríquez, E. Llop, E. Aspillaga, and F. Rothhammer

2006 mtDNA microevolution in Southern Chile's archipelagos. American Journal of Physical Anthropology 129:473-81.

Gilbert, M.T.P., E. Willerslev, A.J. Hansen, I. Barnes, L. Rudbeck, N. Lynnerup, and A. Cooper

2003 Distribution patterns of post- mortem damage in human mitochondrial DNA American Journal of Human Genetics 72:32-47.

Goebel, T., M.R. Waters, and D.H. O'Rourke

2008 The Late Pleistocene dispersal of modern humans in the Americas. Science 319:1497-1502.

González-José, R., M.C. Bortolini, F.R. Santos, and S.L. Bonatto

2008 The peopling of America: Craniofacial shape variation on a continental scale and its interpretation from an interdisciplinary view. American Journal of Physical Anthropology 137:175-187

Handt, O., M. Krings, R. Ward, and S. Pääbo

1996 The retrieval of ancient human DNA sequences. American Journal of Human Genetics 59:368-376.

Höss, M., and S. Pääbo

1993 DNA extraction from Pleistocene bones by a silica-based purification method. Nucleic Acid Research 16:39133914. 
Kaestle, F.A., and D.G. Smith

2001 Ancient mitochondrial DNA evidence for prehistoric population movement: The numic expansion. American Journal of Physical Anthropology 115:1-12.

Kaltwasser, J., A. Medina, and J. Munizaga

1984 El hombre de Cuchipuy. Revista Chilena de Antropología 4:43-48.

Keefer, D.K., S.D. deFrance, M.E. Moseley, J.B. Richardson III, D.R. Satterlee, and A. Day-Lewis

1998 Early maritime economy and El Niño events at Quebrada Tacaguay, Perú. Science 281:1830-1832.

Lalueza, C., A. Perez-Perez, E. Prats, L. Cornudella, D. and Turbon

1997 Lack of founding Amerindian mitochondrial DNA lineages in extinct Aborigines from Tierra del FuegoPatagonia. Human Molecular Genetics 6:41-46.

Mena, F., O. Reyes, T.W. Stafford, and J. Southon

2003 Early human remains from Baño Nuevo-1 cave, central Patagonian Andes, Chile. Quaternary International 109110:113-121.

Moraga, $\mathrm{M}$.

2003 Caracterización Genético-Molecular de Poblaciones Humanas Prehistóricas y Actuales del Norte de Chile. Tesis para optar al Grado de Doctor en Bioquímica, Facultad de Ciencias Químicas y Farmacéuticas, Universidad de Chile, Santiago.

Moraga, M., C. Santoro, V. Standen, P. Carvallo, and F. Rothhammer

2005 Microevolution in prehistoric Andean populations: Chronologic mtDNA variation in the Desert Valleys of Northern Chile. American Journal of Physical Anthropology 127:170-181.

Muñoz, I, B. Arriaza, and A. Aufderheide, editors 1993 Acha 2 y los Orígenes del Poblamiento Humano en Arica. Ediciones Universidad de Tarapacá, Arica.

Nei, M.

1978 Estimation of average heterozygosity and genetic distance from a small number of individuals. Genetics 89:583-590.

Neves, W.A., A. Prous, R. González-José, R. Kipnis, and J. Powell

2003 Early Holocene human skeletal remains from Santana do Riacho, Brazil: implications for the settlement of the New World. Journal of Human Evolution 45:19-42.

Neves, W.A., and M. Hubbe

2005 Cranial morphology of early Americans from Lagoa Santa, Brazil: implications for the settlement of the New World. Proceedings of the National Academy of Sciences USA, 102 o 51??:18309-18314.

Neves, W.A, M. Hubbe, M.M. Okumura, R. González-José, L. Figuti, S. Eggers, P.A. De Blasis

2005 A new early Holocene human skeleton from Brazil: implications for the settlement of the New World. Journal of Human Evolution 48:403-414.

O'Higgins, P.

2000 The study of morphological variation in the hominid fossil record: Biology, landmarks and geometry. Journal of Anatomy 197:103-120.

Parr, R., S. Carlyle, and D. O'Rourke

1996 Ancient DNA analysis of fremont amerindians of the salt lake wetlands. American Journal of Physical Anthropology 99:507-518.

Perego, U.A., A. Achilli, N. Angerhofer, M. Accetturo, M. Pala, A. Olivieri, B.H. Kashani, K.H. Ritchie, R. Scozzari,
Q.P. Kong, N.M. Myres, A. Salas, O. Semino, H.J. Bandelt, S.R. Woodward, and A. Torroni

2009 Distinctive Paleo-Indian migration routes from Beringia marked by two rare mtDNA haplogroups. Current Biology 19:1-8.

Rohlf, F.J.

2005a TPSDig. Version 2.04. Department of Ecology and Evolution. State University of New York, Stony Brook, New York, USA.

2005b TPSUtility. Version 1.34. Department of Ecology and Evolution. State University of New York, Stony Brook, New York, USA.

Rothhammer, F., and T.D. Dillehay

2009 The Late Pleistocene colonization of South America: An interdisciplinary perspective. Annals of Human Genetics 73:540-549.

Saitou, N., and M. Nei

1987 The neighbor-joining method: a new method for reconstructing phylogenetic trees. Molecular Biology and Evolution 4:406-425.

Sandweiss, D.H., H. McInnis, R. Burger, A. Cano, B. Ojeda, R. Paredes, M.del C. Sandweiss, and M. Lascock

1998 Quebrada Jaguay: Early South American maritime adaptations. Science 281:1830-1832.

Schiappacasse, F., and H. Niemeyer

1984 Descripción y análisis interpretativo de un sitio arcaico temprano en la Quebrada de Camarones. DIBAM, Publicación Ocasional $\mathrm{N}^{\circ} 41$, Santiago

Slice, D.

2007 Geometric morphometrics. Annual Review of Anthropology 36:261-281.

Stone, A.C., and M. Stoneking

1996 Genetic analysis of an 8000 Year-old Native American Skeleton Ancient. Ancient Biomolecules 1:85-87.

$1998 \mathrm{mtDNA}$ analysis of a prehistoric Oneota population: Implications for the peopling of the New World. American Journal of Human Genetics 62:1153-1170.

Stothert, K.

1998 An Early Holocene maritime adaptation in Southwest Ecuador: New perspectives on the Las Vegas evidence. Paper presented at 63rd Annual Meeting of the SAA, Seattle.

Tamm, E., T. Kivisild, M. Reidla, M. Metspalu, D. Glenn-Smith, C.J. Mulligan, C.M. Bravi, O. Rickards, C. Martinez-Labarga, and E.K. Khusnutdinova

2007 Beringian standstill and spread of native American founders. Public Library of Science ONE 2:1-6.

Tamura, K., J. Dudley, M. Nei, and S. Kumar

2007 MEGA4: Molecular evolutionary genetics analysis (MEGA) software version 4.0. Molecular Biology and Evolution 24:1596-1599.

Torroni, A., T. Schurr, M. Cabell, M. Brown, J. Nell, M. Larsen, D. Smith, C. Vullo, and D. Wallace

1993 Asian affinities and continental radiation of the four founding native American mtDNAs. American Journal of Physical Anthropology 53:563-590.

Waters, M.R., and T.W. Stafford

2008 Redefining the Age of Clovis: Implications for the peopling of the Americas. Science 315:1122-1126.

Wisner, G.

1999 Early Ecuador people were maritime adapted. Mammoth Trumpet 14(1):4-11.

Wright, $\mathrm{S}$.

1978 Evolution and the Genetics of Populations. Vol. 4. Variability within and among Natural Population. University of Chicago Press, Chicago. 